\title{
Geographical variation in shell shape of the pod razor shell Ensis siliqua (Bivalvia: Pharidae)
}

\author{
Marta M. Rufino - Paulo Vasconcelos • Fábio Pereira • \\ Juan Fernández-Tajes · Susana Darriba $\cdot$ Josefina Méndez $\cdot$ \\ Miguel B. Gaspar
}

Received: 3 November 2011/Revised: 14 March 2012/Accepted: 27 March 2012/Published online: 24 April 2012

(C) Springer-Verlag and AWI 2012

\begin{abstract}
The present study assessed the existence of variation in the shell shape of the pod razor shell (Ensis siliqua) throughout its distributional range in the northeastern Atlantic. Shells of E. siliqua caught at seven collecting sites (three in Portugal, three in Spain and one in Ireland) were studied by geometric morphometric methods, using both landmark- and contour-based methods. Both approaches (landmarks inside the valves and shell outline) discriminated the shells from Aveiro (centre of Portugal) and Strangford Lough (Ireland) from those caught in the nearby localities (remaining Portuguese and Spanish sites,
\end{abstract}

Communicated by Heinz-Dieter Franke.

M. M. Rufino $(\square)$

Centro Interdisciplinar de Investigação Marinha e Ambiental

(CIIMAR), Laboratório Nacional de Energia e Geologia

(LNEG), Departamento de Geologia Marinha (DGM),

Estrada da Portela, Zambujal, Apartado 7586,

2721-866 Alfragide, Portugal

e-mail: marta.m.rufino@gmail.com

P. Vasconcelos · F. Pereira - M. B. Gaspar Instituto Nacional de Recursos Biológicos (INRB, I.P.)/IPIMAR,

Avenida 5 de Outubro s/n, 8700-305 Olhão, Portugal

P. Vasconcelos

Centro de Estudos do Ambiente e do Mar (CESAM),

Departamento de Biologia, Universidade de Aveiro,

Campus de Santiago, 3810-193 Aveiro, Portugal

J. Fernández-Tajes · J. Méndez

Departamento de Biología Celular y Molecular,

Universidade da A Coruña, A Zapateira s/n,

15071 Coruña, Spain

S. Darriba

Instituto Tecnolóxico para o Control do Medio Mariño de

Galicia (INTECMAR), Peirao de Vilaxoán s/n,

36611 Vilagarcía de Arousa, Pontevedra, Spain maximum distance of $550 \mathrm{~km}$ by sea). Landmark analysis revealed that shells from Aveiro were more similar to shells from Ireland ( 1,500 km far away). Contour analysis revealed that shells from Aveiro had a shape with a comparatively larger height-to-width ratio, whereas shells from Ireland showed a slightly more curved outline than in the remaining sites. Landmark- and contour-based methods provided coherent complementary information, confirming the usefulness of geometric morphometric analyses for discerning differences in shell shape among populations of E. siliqua. A brief review of previous applications of geometric morphometric methods to modern bivalve species is also provided.

Keywords Pod razor shell - Ensis siliqua - Shell shape · Geometric morphometrics

\section{Introduction}

The comparison of anatomical features of organisms has been a central element in biology for centuries (Adams et al. 2004). Shell morphology, which preserves the ontogenetic record of growth, is now the principal subject of a subfield of morphometrics (Madec et al. 2003), namely theoretical morphology, which since the initial mathematical modelling of Raup (1966) has led to convincing studies on the formal and historical determinants of shell forms, as well as functional interpretations of their observed distributions in theoretical morphospaces (e.g. Stone 1996, 1999; McGhee 1999; Samadi et al. 2000). Several models of theoretical morphology of molluscan shells have been successfully developed in previous studies (Savazzi et al. 1982; Savazzi 1989, 1990; McClain et al. 2004). In more traditional approaches, the shape of molluscan shells has 
also been characterised by using simpler measurements, such as the ratio of width to height (for a review see Goodfriend 1986), or by plotting these two measurements in order to create a "size/shape space" (Cain 1981; Cameron and Cook 1989). More recently, geometric morphometric (GM) methods allowed the partitioning of shape and size components, preserving the main geometric properties of the specimens and generating a visual representation and shape variables than can be statistically analysed. GM is often described as a "revolution" in the area of morphometrics (Adams et al. 2004) and has been successfully applied in most fields of science, since these techniques are useful for biology, ecology, evolution, ontogeny, taxonomy, among other studies.

Due to their hard un-deformable shells, bivalves are an excellent group to apply GM methods (Rufino et al. 2007). Historically, GM techniques have been developed within two main approaches: (1) the analysis of outline or contour, where the frontier/border of a specimen is analysed (Rohlf and Archie 1984) and (2) the analysis of landmarks, where the change in position of homologous points identified in the specimens is quantified. Recent studies use a mixture of these two techniques, called semi-landmarks. Both approaches provide different types of information and can be applied in distinct circumstances. The first GM studies with bivalves used mainly contour-based methods (Ferson et al. 1985; Innes and Bates 1999), whereas presently most works employ landmarks or a combination of both approaches, which have been considered to be more powerful (Rufino et al. 2007). These techniques have been successfully applied to distinguish similar species of bivalves (Rufino et al. 2007; Costa et al. 2010), between fossil and modern specimens (Aguirre et al. 2006; Gordillo et al. 2011) or between wild and aquaculture stocks (Valladares et al. 2010), to detect ontogenetic shape changes (Márquez et al. 2010a) and to analyse geographical variation in shape (Palmer et al. 2004; Sousa et al. 2007; Costa et al. 2008; Márquez et al. 2010b; Gordillo et al. 2011; Márquez and Van der Molen 2011). A compilation of previous works that applied GM methods to modern bivalves is summarised in Table 1 .

The pod razor shell Ensis siliqua (Linnaeus, 1758) is distributed in the Mediterranean Sea and in the Atlantic Ocean, from Morocco to Norway (Tebble 1966), being commercially exploited in Portugal, Spain, Ireland and UK (Guerra and Lodeiros 2008). The most common methods used to harvest E. siliqua are hand-gathering (Fahy and Carroll 2007; Constantino et al. 2009), and mechanic or hydraulic dredging (Gaspar and Monteiro 1998; Robinson and Richardson 1998; Gaspar et al. 1999; Tuck et al. 2000; Fahy and Gaffney 2001; Hauton et al. 2003a, b). This infaunal species inhabits the low intertidal zone down to
40 m depth (Fahy and Gaffney 2001; Rufino et al. 2010), occurring in substrates of fine to medium sand. It lives burrowed into the sediment with the long axis of the shell orientated roughly vertical, extending the siphons out of the surface to feed on suspended particles (Gaspar and Monteiro 1998; Gaspar et al. 1999; Fahy and Gaffney 2001; Rufino et al. 2010). The pod razor shell has a large and powerful foot that enables vertical burrowing into sand up to $60 \mathrm{~cm}$ depth. The characteristic shape of the shell of E. siliqua, elongated, laterally compressed, narrowed and with almost semi-cylindrical valves, facilitates rapid burrowing.

Most previous studies with E. siliqua have focused on life cycle and growth (Henderson and Richardson 1994; Gaspar and Monteiro 1998; Fahy and Gaffney 2001; Darriba et al. 2005; da Costa et al. 2010), larval cycle and aquaculture potential (Darriba et al. 2005; da Costa et al. 2010), genetics (Fernández-Tajes et al. 2007; Varela et al. 2007; Freire et al. 2008; Arias et al. 2011) or on fisheryrelated aspects (Robinson and Richardson 1998; Gaspar et al. 1999; Tuck et al. 2000; Fahy and Gaffney 2001; Hauton et al. 2003a, b; Constantino et al. 2009). To the author's best knowledge, the shell shape of E. siliqua has never been analysed by applying GM approaches. Therefore, the present study aimed to analyse and compare the shape of E. siliqua shells across its distributional range in the north-eastern Atlantic (Portugal, Spain and Ireland), using both landmark- and contour-based methods, in order to assess the suitability of these techniques for discerning populations of this species.

\section{Materials and methods}

\section{Study area and sample collection}

Individuals of E. siliqua with a shell length ranging from 12 to $15 \mathrm{~cm}$ were caught by scuba diving or by dredging at seven collecting sites: three sites in Portugal (OlhãoPO, Setúbal-PS and Aveiro-PA), three sites in Spain (Barra de Cangas-SB, Fisterra-SF and Celeiro-SC) and one site in Ireland (Strangford Lough-IS) (Fig. 1). The southernmost and northernmost collecting sites are separated by approximately 17 degrees of latitude (Olhão $\approx 37^{\circ} \mathrm{N}$ and Strangford Lough $\approx 54^{\circ} \mathrm{N}$ ), corresponding to a distance of almost 2,000 km (more than 1,000 nmi). In the laboratory, the soft parts were removed and the valves were cleaned, air-dried and stored for subsequent analyses.

In order to decrease unpredictable sources of variability, only the right valve of each shell was used for GM purposes. A preliminary analysis of E. siliqua shells revealed that the muscle scars on the inner surface of the valves 
Table 1 Compilation of previous studies that applied geometric morphometric methods to modern bivalves

\begin{tabular}{|c|c|c|c|c|}
\hline Species & $\begin{array}{l}\text { Country or geographical } \\
\text { area }\end{array}$ & Type/subject & Contour/landmarks & Reference \\
\hline Mytilus sp. & & & Elliptic Fourier analysis & Ferson et al. (1985) \\
\hline $\begin{array}{l}\text { Mytilus edulis } \\
\text { Mytilus trossulus }\end{array}$ & $\begin{array}{l}\text { Canada (eastern } \\
\text { Newfoundland) (16) }\end{array}$ & Multispecies & $\begin{array}{l}300-600 \text { points, } \\
10 \text { harmonics }\end{array}$ & Innes and Bates (1999) \\
\hline Chamelea gallina & Spain (6), Italy (1) & Geographical & 100 points, 10 harmonics & Palmer et al. (2004) \\
\hline $\begin{array}{l}\text { Brachidontes darwinianus } \\
\text { Brachidontes purpuratus } \\
\text { Brachidontes rodriguezi }\end{array}$ & $\begin{array}{l}\text { Argentina: Quaternary } \\
\text { fossils (19), modern (8) }\end{array}$ & $\begin{array}{l}\text { Fossil/modern } \\
\text { multispecies } \\
\text { geographical }\end{array}$ & $\begin{array}{l}1 \text { landmark (umbo) }+39 \\
\text { semi-landmarks }\end{array}$ & Aguirre et al. (2006) \\
\hline Mytilus chilensis & Chile (8) & Geographical & 100 points, 10 harmonics & Krapivka et al. (2007) \\
\hline $\begin{array}{l}\text { Chamelea gallina } \\
\text { Chamelea striatula }\end{array}$ & Portugal (1) & Multispecies & 10 harmonics +9 landmarks & Rufino et al. (2007) \\
\hline Corbicula fluminea & Portugal (6) & Geographical & 11 landmarks & Sousa et al. (2007) \\
\hline $\begin{array}{l}\text { Ruditapes decussatus } \\
\text { Ruditapes philippinarum }\end{array}$ & $\begin{array}{l}\text { Italy (9), Spain (1), } \\
\text { Tunisia (1) }\end{array}$ & $\begin{array}{l}\text { Multispecies } \\
\text { geographical }\end{array}$ & 7 harmonics & Costa et al. (2008) \\
\hline $\begin{array}{l}\text { Anomalocardia brasiliana } \\
\text { Anomalocardia squamosa } \\
\text { Iliochione subrugosa }\end{array}$ & $\begin{array}{l}\text { Thailand (7), } \\
\text { Philippines (1), } \\
\text { Jamaica (1), } \\
\text { Colombia (1), } \\
\text { Brazil (1), } \\
\text { Ecuador (1) }\end{array}$ & $\begin{array}{l}\text { Multispecies } \\
\text { geographical }\end{array}$ & 19 landmarks & Roopnarine et al. (2008) \\
\hline $\begin{array}{l}\text { Mytilus edulis } \\
\text { Mytilus galloprovincialis } \\
\text { Mytilus trossulus }\end{array}$ & $\begin{array}{l}\text { Canada (7), USA (1), } \\
\text { UK (5), France (1), } \\
\text { Finland (1) }\end{array}$ & $\begin{array}{l}\text { Multispecies } \\
\text { geographical }\end{array}$ & $\begin{array}{l}300-600 \text { points, } \\
10 \text { harmonics }\end{array}$ & $\begin{array}{l}\text { Gardner and Thompson } \\
\text { (2009) }\end{array}$ \\
\hline $\begin{array}{l}\text { Ruditapes decussatus } \\
\text { Ruditapes philippinarum }\end{array}$ & Italy (2) & Multispecies & $\begin{array}{l}180 \text { points, } \\
7 \text { harmonics }\end{array}$ & Costa et al. (2010) \\
\hline Aequipecten tehuelchus & Argentina (1) & Ontogenetic & $\begin{array}{l}8 \text { landmarks }+ \\
20 \text { semi-landmarks }\end{array}$ & Márquez et al. (2010a) \\
\hline Ameghinomya antiqua & Argentina (5) & Geographical & $\begin{array}{l}10 \text { harmonics }+ \\
13 \text { landmarks }\end{array}$ & Márquez et al. (2010b) \\
\hline Mytilus chilensis & Chile (6) & $\begin{array}{l}\text { Geographical wild } \\
\text { versus cultivated }\end{array}$ & 9 landmarks & Valladares et al. (2010) \\
\hline $\begin{array}{l}\text { Tawera gayi } \\
\text { Tawera philomela } \\
\text { Tawera spissa }\end{array}$ & $\begin{array}{l}\text { Chile (3), Argentina (2), } \\
\text { New Zealand (1), } \\
\text { South Africa (1) }\end{array}$ & $\begin{array}{l}\text { Fossil/modern } \\
\text { multispecies } \\
\text { geographical }\end{array}$ & 10 harmonics & Gordillo et al. (2011) \\
\hline Ensis macha & Argentina (12) & Geographical & 15 harmonics & $\begin{array}{l}\text { Márquez and Van der } \\
\text { Molen (2011) }\end{array}$ \\
\hline Pectinidae & USA & Multispecies & $\begin{array}{l}\text { Sliding semi- } \\
\text { landmarks in 3D }\end{array}$ & Serb et al. (2011) \\
\hline
\end{tabular}

The number of sites or populations analysed is indicated between brackets. In contour and landmark analyses, the number of points or harmonics and the number of landmarks are also indicated

were very difficult to identify, and thus to increase precision, shells were examined under a binocular microscope and the selected landmarks were carefully marked with a pen. Each valve was then digitised using a previously calibrated $\mathrm{HP}^{\circledR}$ Scanjet 5530 before subsequent GM analyses. The number of valves subjected to landmark and contour analyses differed due to the adequacy of each valve for the method employed. Indeed, valves with slightly damaged margins can be used for landmark analysis but not for contour analysis.
Landmark analysis

A total of 334 individuals were used for landmark analysis: 159 valves from Portugal $(\mathrm{PO}=112, \mathrm{PS}=28$ and $\mathrm{PA}=19), 119$ valves from Spain $(\mathrm{SB}=49, \mathrm{SF}=60$ and $\mathrm{SC}=10)$ and 56 valves from Ireland (IS $=56$ ). In each valve, 11 shell landmarks were selected to quantify shape: the first, second and third landmarks were located at the pallial sinus, the fourth and fifth in the limits of the scar of the posterior adductor muscle, the sixth and seventh 
Fig. 1 Geographical location of the collecting sites of the pod razor shell (Ensis siliqua) in Portugal (Olhão-PO, Setúbal- $P S$ and Aveiro- $P A)$, Spain (Barra de Cangas- $S B$, Fisterra- $S F$ and Celeiro- $S C$ ) and Ireland (Strangford Lough-IS)

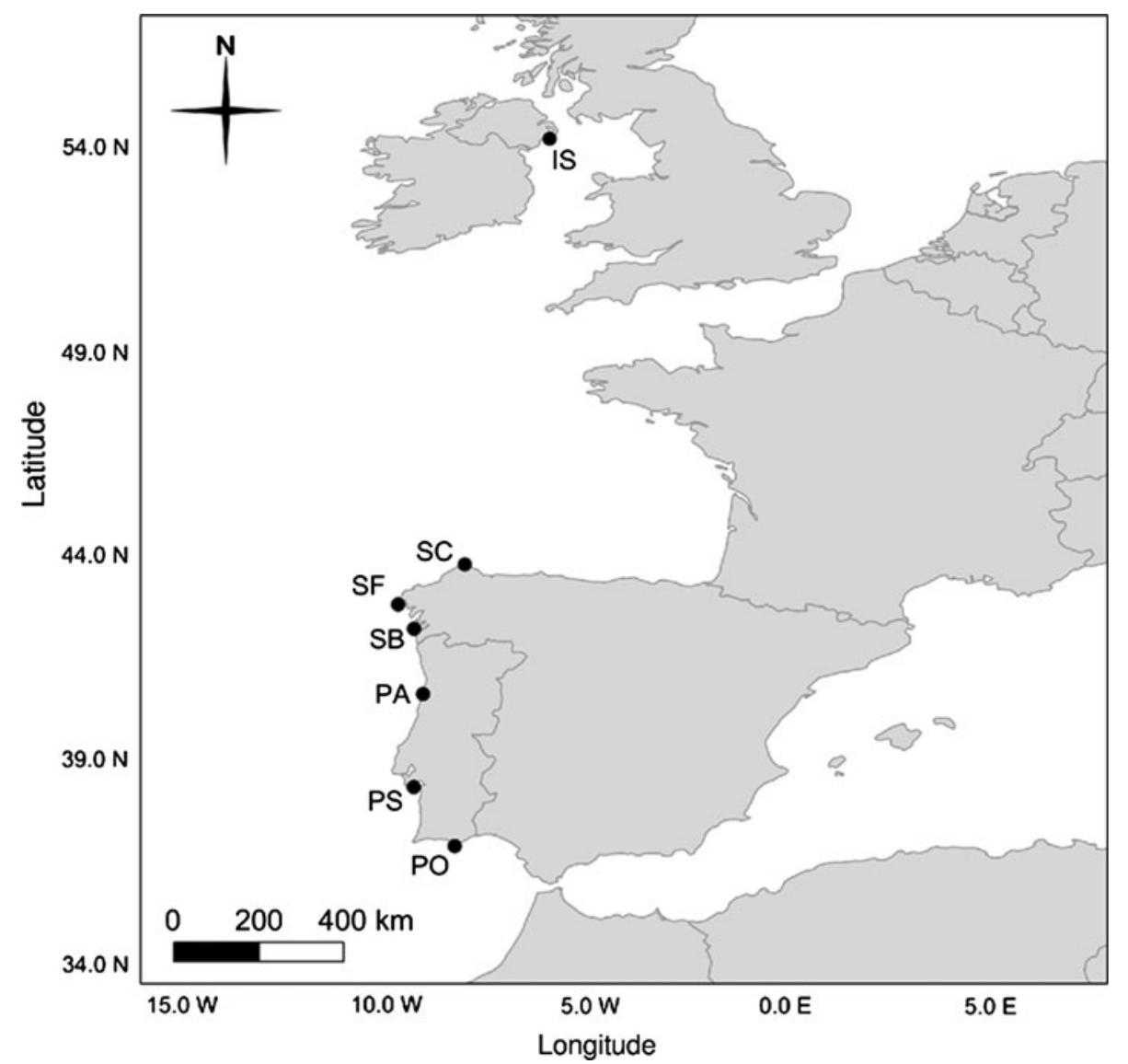

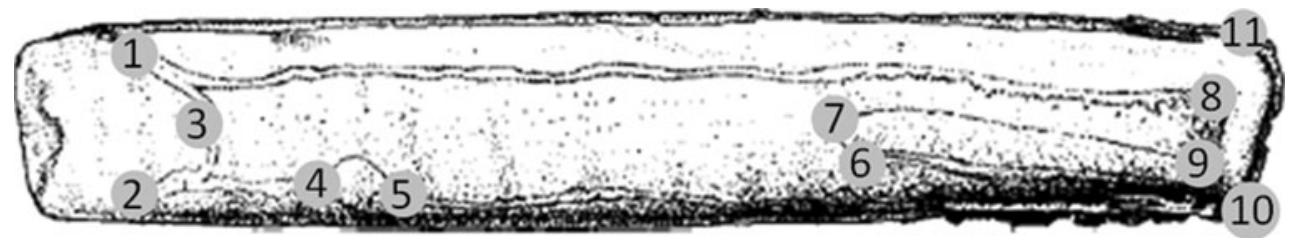

Fig. 2 Location and description of the landmarks in the inner surface of the shell of Ensis siliqua: (1) ventralmost point of the pallial sinus, (2) centralmost point (maximum curvature) of the pallial sinus, (3) dorsalmost point of the pallial sinus, (4) posteriormost point of the posterior adductor muscle, (5) anteriormost point of the posterior adductor muscle, (6) dorsalmost point of the posterior limit of the

corresponded to the posterior limits of the scar of the anterior adductor muscle, the eighth and ninth were located at the anterior limits of pallial line, whereas the tenth and eleventh (pseudo-landmarks) were located in the anterior margin of the valve (Fig. 2). Because most valves analysed were damaged in the posterior margin, no landmarks were selected in this area of the shell.

A more detailed description of GM methods using landmarks has been reported by Adams et al. (2004); therefore, only a brief explanation is provided here. After digitisation, landmark positions were rotated, scaled (to anterior adductor muscle, (7) ventralmost point of the posterior limit of the anterior adductor muscle, $(8)$ ventral anterior limit of the pallial line, (9) dorsal anterior limit of the pallial line, (10) dorsalmost point of the anterior margin of the valve (pseudo-landmark), (11) ventralmost point of the anterior margin of the valve (pseudo-landmark)

unit centroid size) and translated through Generalized Procrustes Analysis (GPA), a procedure that eliminates variation due to differences in scale, size and orientation. An average map (consensus configuration) of the shell shape, plus the uniform and non-uniform (partial warps) components of shape variation were calculated. The two uniform components describe differences that affect equally all parts of the shell (global differences). The nonuniform components (partial warps) describe localised departures from the average map of the shell. Partial warps together with uniform component are the statistical 
variables of shell shape. The effect of size (allometry) was tested through permutation bifactorial multivariate ANOVA applied to partial warps and uniform component, treating centroid size and geographical location (collecting site) as independent variables.

To check whether the shape variables were normally distributed, Shapiro-Wilk test for multivariate normality was performed (mvnormtest package; Jarek 2009), followed by permutational multivariate analysis of variance (adonis, vegan package; Oksanen et al. 2010), to determine whether there were significant differences depending on geographical location (collecting site) or whether there was a significant allometric effect (i.e. shape changes with size, quantified as centroid size). Relative warp analysis, a technique analogous to principal component analysis, was applied to determine the patterns of shape variation. The mean landmark configuration of the extremes of the two principal relative warps was estimated to determine which landmarks were varying. Coordinates of the landmarks were calculated from the digitised images of the shells using tpsDig (Rohlf 2003a). Partial warps and centroid size were calculated using tpsReg (Rohlf 2000), and relative warps were estimated using tpsRel (Rohlf 2003b). All other statistical analyses and graphical representations were performed using the free software R ( R Development Core Team 2010).

\section{Contour analysis}

A total of 224 individuals were examined for contour analysis: 128 valves from Portugal $(\mathrm{PO}=86, \mathrm{PS}=27$ and $\mathrm{PA}=15), 66$ valves from Spain $(\mathrm{SB}=26, \mathrm{SF}=33$ and $\mathrm{SC}=7$ ) and 30 valves from Ireland (IS $=30$ ). The overall shell shape was studied through elliptic Fourier analysis of the contour coordinates (Rohlf and Archie 1984). For each shell, 100 coordinates of the outline were obtained using tpsDig (Rohlf 2003a). In a preliminary study based on visual inspection, it was concluded that 15 harmonics were sufficient to properly characterise the shell shape of $E$. siliqua, similar to the study by Márquez and Van der Molen (2011) with E. macha. As recommended by Rohlf and Archie (1984), 59 elliptic Fourier coefficients were normalised mathematically to be invariant of size, location, rotation and starting position (which was always approximately the left lower extreme of the shell). All further Fourier analyses were performed using the software Morpheus (Slice 1998). The mean outline of the shells of E. siliqua from each collecting site was reconstructed using Fourier analysis. The ShapiroWilk test for multivariate normality was applied to the harmonic coefficients to verify whether the data presented a Gaussian multivariate distribution (mvnormtest package; Jarek 2009), followed by permutational multivariate analysis of variance (adonis, vegan package; Oksanen et al. 2010).

\section{Results}

Landmark analysis

After a detailed preliminary analysis, 11 landmarks were found essential to properly describe the main shape features of the shells of E. siliqua. Centroid size of the individuals differed between collecting sites (Fig. 3), with a north-south decreasing trend in mean shell length, which was largest in E. siliqua from Strangford Lough (IS) and smallest in Olhão (PO) (Kruskal-Wallis rank sum test: $H=179.727, P<0.001)$. Still, there was some overlap in sizes across all collecting sites, which allowed both to compare the shape of the bivalves and to test for an eventual allometric effect.

The shape variables were not normally distributed (Shapiro-Wilks test for multivariate normality: $W=0.764$, $P<0.001)$ and the variances differed significantly between collecting sites (Anderson's multivariate homogeneity of group dispersions: ANOVA: $F=18.208$, $P<0.001$; Anderson 2006), with the shells from Olhão (PO) showing greater dispersions than the remaining samples. Therefore, nonparametric MANOVA was used to test for shape differences (Anderson 2001) between collecting sites, using centroid size as covariable. The nonparametric MANOVA indicated that both the covariable

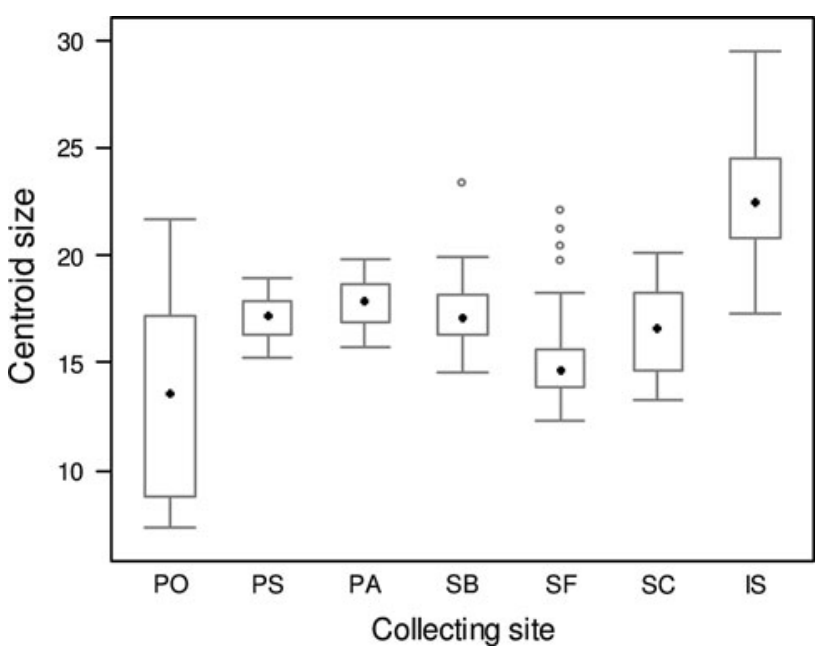

Fig. 3 Centroid size (square root of the sum of squared distances of a set of landmarks from their centroid as an accurate measure of size) in the shells of Ensis siliqua from each collecting site. The central dot represents the median, the limits of the box, the first and third quartiles, and the whiskers, the $95 \%$ confidence interval. Abbreviations: Olhão- $P O$, Setúbal- $P S$, Aveiro- $P A$, Barra de Cangas$S B$, Fisterra- $S F$, Celeiro- $S C$ and Strangford Lough $-I S$ 
centroid size $\left(r^{2}=0.011, F=5.182, P=0.003\right)$ and the collecting site $\left(r^{2}=0.254, F=18.832, P=0.001\right)$ were significantly different, whereas their interaction was not statistically significant $\left(r^{2}=0.015, \quad F=1.136, \quad P=\right.$ 0.286). In practice, this means that there is a significant change in shape with size (allometry), as well as significant differences in shape between collecting sites, but the change in shape with specimen size is similar for all studied populations.

Relative warp analysis showed clear trends in shape change, although with overlap of points in all collecting sites, typical in this kind of morphometric data (Fig. 4). The first three relative warps (RW1, RW2 and RW3) explained 50.4, 13.8 and $5.8 \%$ of shape variability, respectively. The RW1 shows the main axis of shape change, distinguishing the shells from Aveiro (PA) and Strangford Lough (IS) from those of Olhão (PO), with the remaining populations being intermediate. The reconstruction of shape variation on this axis allowed detecting that the main changes occurred in the distance between landmark 3 and both landmarks 4-5 and 6-7, which was smaller in PA and IS than in shells from other collecting sites. In practice, this means that $E$. siliqua from PA and IS have the pallial sinus (landmark 3 ) closer to the scars of the posterior (landmarks 4 and 5) and anterior adductor muscles (landmarks 6 and 7) than E. siliqua from PO. Furthermore, these shells from Olhão (PO) presented two peaks of shape distribution over the RW1, which had no correspondence with centroid size, indicative of some morphological plasticity in this population. The RW2 detected some differences between the shells from Aveiro (PA, in the positive extreme) and the shells from Strangford Lough (IS, in the negative extreme), with the remaining populations being intermediate (Fig. 4). The shape reconstruction for the RW2 extremes revealed that shells in the positive side (where shells from PA are located) have greater distance between landmarks 4-5 and 6-7 than those in the negative side (where shells from IS are located). In practice, this means that E. siliqua from PA have a relatively longer body between the scars of the posterior (landmarks 4 and 5) and anterior adductor muscles (landmarks 6 and 7) than those from IS, with the remaining populations being intermediate between these two morphs.

The linear model of the RW1 with centroid size and collecting site showed that the main effects were both
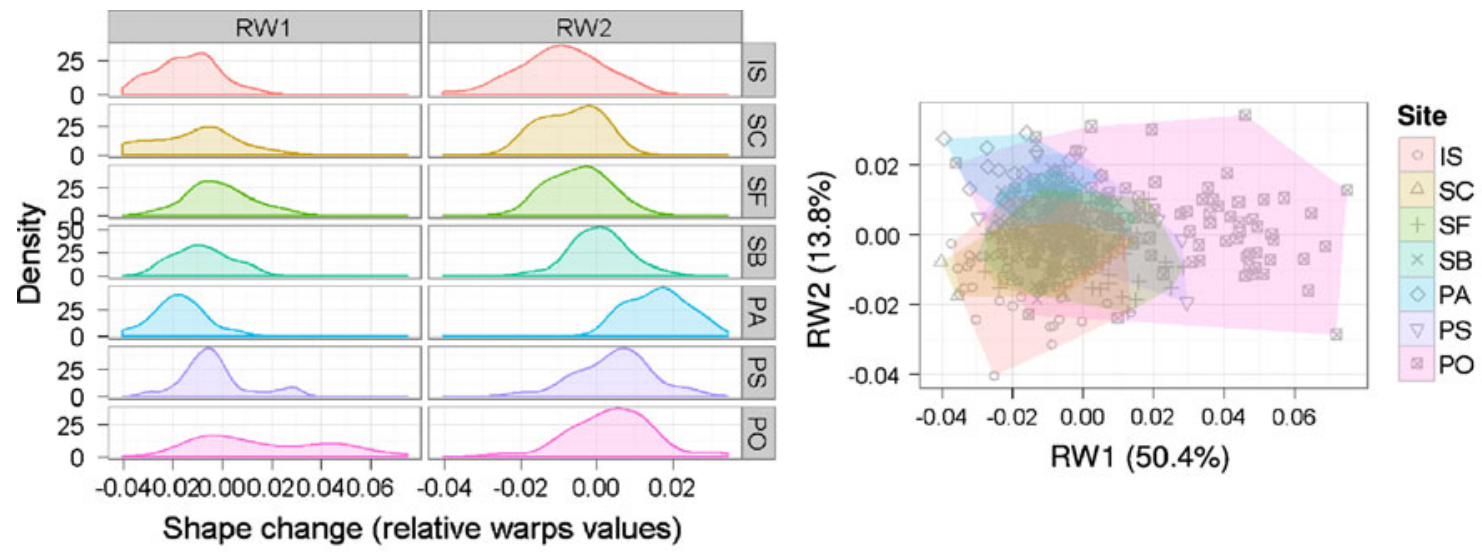

Reconstruction of relative warps axes extremes:

Relative warp 1
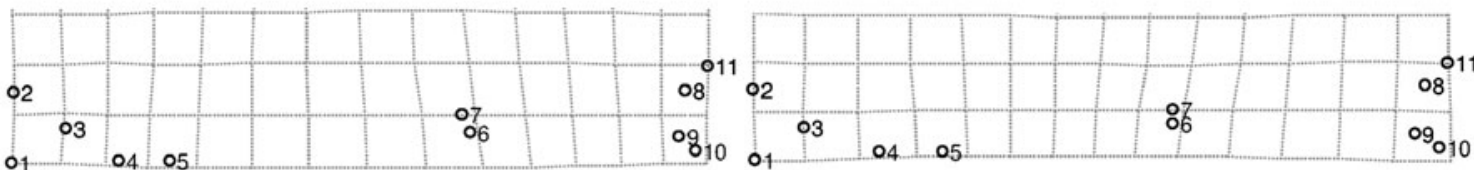

Relative warp 2
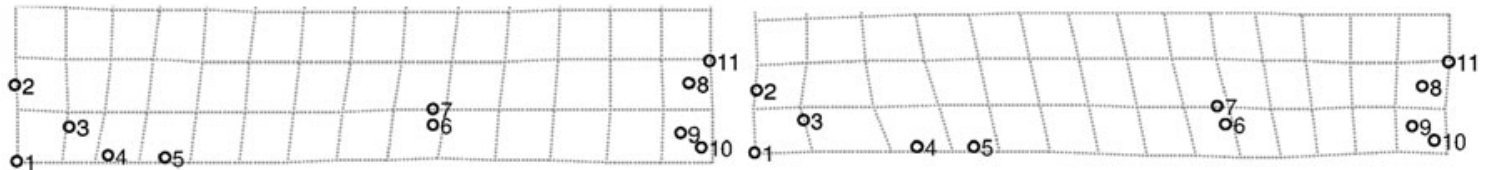

Fig. 4 Relative warp analysis of the landmarks in the shells of Ensis siliqua from each collecting site and respective shape TPS reconstruction of main axis of variation. Abbreviations: Olhão-PO,

Setúbal- $P S$, Aveiro- $P A$, Barra de Cangas- $S B$, Fisterra- $S F$, Celeiro- $S C$ and Strangford Lough $-I S$ 


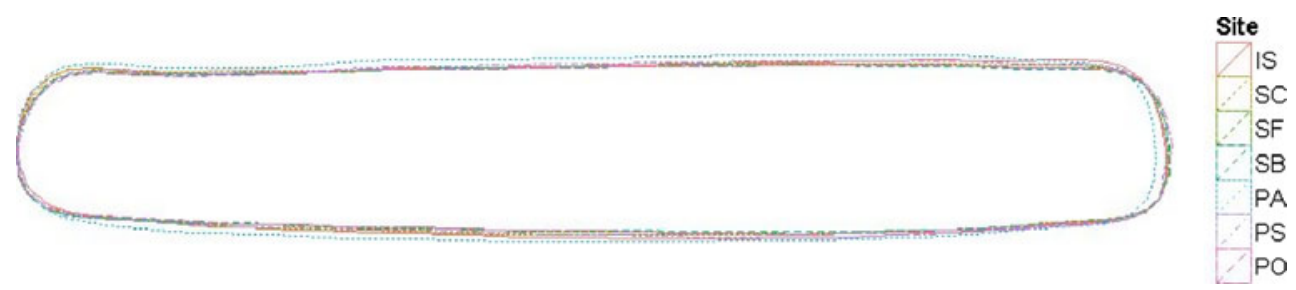

Fig. 5 Mean contour of the shells of Ensis siliqua from each collecting site, reconstructed using Fourier analysis. Abbreviations: Olhão-PO, Setúbal- $P S$, Aveiro- $P A$, Barra de Cangas $-S B$, Fisterra- $S F$, Celeiro- $S C$ and Strangford Lough $-I S$

significant (ANCOVA: $F$ centroid $=8.881, P=0.003$; $F$ site $=11.265, P<0.001)$, although without significant interaction between them (ANCOVA: $F$ interaction $=$ $0.796, P=0.574)$. Altogether, this revealed that the relationship between the RW1 and centroid size was not significantly different among collecting sites, thus not relevant in terms of shape change across this axis. Furthermore, the plot of the residuals (data omitted for brevity) showed similar results and confirmed this same trend.

\section{Contour analysis}

The harmonic coefficients were not normally distributed (Shapiro-Wilks test for multivariate normality: $W=$ $0.193, P<0.001)$ and the variances differed significantly between collecting sites (Anderson's multivariate homogeneity of group dispersions: ANOVA $F_{[6,217]}=3.642$, $P=0.001$; Anderson 2006), with the shells of E. siliqua from Setúbal (PS) and Strangford Lough (IS) showing greater dispersions than the remaining samples. The nonparametric MANOVA confirmed the existence of significant differences in the contour of shells between collecting sites $\left(r^{2}=0.227, F=10.624, P<0.001\right)$. The mean shell outline in each collecting site in relation to the global mean revealed that E. siliqua from Aveiro (PA) have thicker and shorter shells than in the remaining collecting sites, whereas shells from Strangford Lough (IS) are slightly more curved (Fig. 5).

\section{Discussion}

Geometric morphometric methods applied in the study of E. siliqua shell morphology were able to discern three main shapes, corresponding to different geographical groups among seven collecting sites distributed along the northeastern Atlantic coasts (Portugal, Spain and Ireland). As in previous studies, both landmark- and contour-based methods were used, because these provide different and complementary information, namely on the position of internal features of the shell (landmark analysis) that are related with physiological aspects (e.g. muscle scars), as well as on the shell outline (contour analysis). Still, both approaches provided coherent complementary results, separating the populations of E. siliqua of Aveiro (Portugal) and Strangford Lough (Ireland) from the remaining collecting sites. Indeed, the first relative warp showed that the shells from Aveiro (PA) were more similar to those from Strangford Lough (IS), which is located more than $1,500 \mathrm{~km}$ apart (around $840 \mathrm{nmi}$ ), than to the shells from the other Portuguese (PO and PS) and Spanish (SB, SF and SC) sites, which are situated within a maximum distance slightly over $400 \mathrm{~km}$ (almost $220 \mathrm{nmi}$ ). The shells from Olhão (PO) extended throughout the first relative warp, denoting a certain degree of morphological plasticity in this southernmost population of $E$. siliqua. On the whole, combining the results gathered using both methods (landmark and contour analyses), three main groups with different shell shape were identified: one morph from Strangford Lough (IS), another from Aveiro (PA) and another comprising the remaining populations of $E$. siliqua from the Iberian Peninsula (Portugal: PO and PS; Spain: SB, SF and SC).

The results from landmark analysis are corroborated by recent genetic studies with E. siliqua, where the larger differences were observed between Iberian and Irish populations, except for Aveiro individuals that were closer to northern individuals (Arias et al. 2011). These authors argued that the Aveiro population might be predominantly self-recruiting, as a consequence from some mechanism that could affect larval dispersal of E. siliqua. A recent geophysical model, where particles simulating larvae were released into the main Portuguese estuaries, estimated an along shore dispersal distance around $60 \mathrm{~km}$ for crab zoeae and greater than $100 \mathrm{~km}$ for crab megalopae (Peliz et al. 2007). Furthermore, these authors concluded that larvae released in the Ria de Aveiro can easily reach northern estuaries up to Minho River, and only if these estuaries are also sources of larvae, these could reach Fisterra, but not northern than this location. These findings support the similarities in shell shape among the Spanish populations of E. siliqua (SB, SF and SC), but do not explain the differences in shape between the shells from Aveiro (PA) and from the other collecting sites along the Portuguese ( $\mathrm{PO}$ and PS) and Spanish (SB, SF and SC) coasts. Peliz et al. (2007) also found little transport southern of the Mondego River, which excludes larval transport by along shore 
currents as a factor responsible for the similarities observed between the shells of E. siliqua from Portuguese (PO and PS) and Spanish (SB, SF and SC) populations. Moreover, crab larvae have a longer pelagic larval duration than E. siliqua, which under laboratory conditions lasts for only 15-20 days before settlement (Darriba et al. 2005; da Costa et al. 2010). Probably for this reason, the pod razor shell is a typical inhabitant of sandy beaches, whose larvae find settlement spots in the vicinities of the source populations along the coasts of the Iberian Peninsula.

As mentioned above, there was a recent study focusing on the genetic identification of E. siliqua populations along the north-eastern Atlantic (Arias et al. 2011). However, the phenotype of an organism does not always directly reflect its genotype information, and often genetic evidence does not match with results from shape analysis (Lawing and Polly 2009). In addition, results from genetic studies greatly depend on the methods applied and on the markers used. For instance, Sousa et al. (2007) studying an invasive bivalve in two Portuguese estuaries were able to identify morphological differences through GM methods, where no genetic evidences were observed. Indeed, GM is an excellent tool to identify phenotypic differences related to environmental specificities in different locations and thus ideal to study geographical shape changes. Arias et al. (2011) considered that genetic similarities between populations of E. siliqua from Aveiro (Portugal) and Ireland are most likely due to anthropogenic influence, for instance through larval transport in ballast water of ships. However, although the existence of an important commercial harbour, a shipyard and a fishing port in the Ria de Aveiro, routes connecting Aveiro and Ireland are certainly sporadic.

Morphometrics is an evolving discipline, providing increasingly powerful techniques for quantitative characterisation and comparison of shape (Roth and Mercer 2000). Before the 1990s, morphometric tools were restricted to bivariate plots and multivariate statistics (Urdy et al. 2010a), but since then enhancements included the development of GM that more directly preserve geometry and the spatial relationships among landmark points and the contours of a form (Roth and Mercer 2000). Bivalves have hard shells, which make them excellent candidates for geographical studies of morphological variation in individuals from different populations, based solely on the analysis of their shape profiles (Costa et al. 2008). In the present study, the use of two complementary GM methods (landmark and contour analysis) was fundamental. Shape differences detected in E. siliqua caught at several collecting sites were not limited to the shell outline, but also occurred in the inner surface of the valves, that is reflecting differences in the internal structure of the bivalves. Variation in mollusc shell morphology can be both genetically and environmentally determined. However, although there is an extensive literature on correlations between some environmental aspects and mollusc shell shapes (Urdy et al. $2010 \mathrm{~b}$ ), the contribution of local adaptation to morphological differentiation of bivalve populations is still poorly studied (Costa et al. 2008). In this context, further research should focus on the phenotypic variation and morphological plasticity of the shell of E. siliqua as a function of different environmental conditions (e.g. hydrodynamics, depth, sediment type and grain size). Altogether, these environmental variables are known to influence bivalve's burrowing ability and thus might also play a key role in the geographical variation in shell shape of E. siliqua.

Acknowledgments The authors would like to thank Dr. Dai Roberts and Adele Cromie for providing samples of pod razor shells from Ireland. This study was funded by Community Initiative Programmes (INTERREG-IIIB, Atlantic Area) Sustainable HARvesting of Ensis (090-SHARE) and Towards Integrated Management of Ensis Stocks (206-TIMES) from the European Community. Marta M. Rufino and Paulo Vasconcelos benefited from postdoctoral grants (SFRH/BPD/ 14935/2004 and SFRH/BPD/26348/2006, respectively) awarded by the Fundação para a Ciência e Tecnologia (FCT-Portugal). Finally, the authors acknowledge three anonymous referees for valuable comments and suggestions that greatly improved the revised manuscript.

\section{References}

Adams DC, Rohlf FJ, Slice D (2004) Geometric morphometrics: ten years of progress following the "revolution". Ital J Zool 71:5-16

Aguirre ML, Perez SI, Sirch YN (2006) Morphological variability of Brachidontes Swainson (Bivalvia, Mytilidae) in the marine Quaternary of Argentina (SW Atlantic). Palaeogeogr Palaeoclimatol Palaeoecol 239:100-125

Anderson MJ (2001) A new method for non-parametric multivariate analysis of variance. Austral Ecol 26:32-46

Anderson MJ (2006) Distance-based tests for homogeneity of multivariate dispersions. Biometrics 62:245-253

Arias A, Fernández-Moreno M, Fernández-Tajes J, Gaspar MB, Méndez J (2011) Strong genetic differentiation among east Atlantic populations of the sword razor shell (Ensis siliqua) assessed with mtDNA and RAPD markers. Helgol Mar Res 65:81-89

Cain AJ (1981) Variation in shell shape and size of helicid snails in relation to other pulmonates in faunas of the Palaearctic region. Malacologia 21:149-176

Cameron RAD, Cook LM (1989) Shell size and shape in Madeiran land snails—do niches remain unfilled. Biol J Linn Soc 36:79-96

Constantino R, Gaspar MB, Pereira F, Carvalho S, Cúrdia J, Matias D, Monteiro CC (2009) Environmental impact of razor clam harvesting using salt in Ria Formosa lagoon (southern Portugal) and subsequent recovery of associated benthic communities. Aquat Conserv Mar Freshwat Ecosyst 19:542-553

Costa C, Aguzzi J, Menesatti F, Antonucci F, Rimatori V, Mattoccia M (2008) Shape analysis of different populations of clams in relation to their geographical structure. J Zool 276:71-80

Costa C, Menesatti P, Aguzzi J, D’Andrea S, Antonucci F, Rimatori V, Pallottino F, Mattoccia M (2010) External shape differences between sympatric populations of commercial clams Tapes decussatus and T. philippinarum. Food Bioprocess Technol $3: 43-48$ 
da Costa F, Martínez-Patiño D, Ojea J, Nóvoa S (2010) Larval rearing and spat production of the razor clam Ensis siliqua (Bivalvia: Pharidae). J Shellfish Res 29:347-351

Darriba S, San Juan F, Guerra A (2005) Gametogenic cycle of Ensis siliqua (Linnaeus, 1758) in the Ría de Corcubión, northwestern Spain. J Mollus Stud 71:47-51

Fahy E, Carroll J (2007) Consequences of hydraulic dredging for a razor clam Ensis siliqua (L.) bed in the north-west Irish Sea. Biol Environ 107B:115-128

Fahy E, Gaffney J (2001) Growth statistics of an exploited razor clam (Ensis siliqua) bed at Gormanstown, Co Meath, Ireland. Hydrobiologia 465:139-151

Fernández-Tajes J, Gaspar MB, Martínez-Patiño D, McDonough N, Roberts D, González-Tizón A, Martínez-Lage A, Méndez J (2007) Genetic variation of the razor clam Ensis siliqua (Jeffreys, 1875) along the European coast based on random amplified polymorphic DNA markers. Aquacult Res 38:12051212

Ferson SF, Rohlf FJ, Koehn RK (1985) Measuring shape variation of two-dimensional outlines. Syst Zool 34:59-68

Freire R, Fernández-Tajes J, Méndez J (2008) Identification of razor clams Ensis arcuatus and Ensis siliqua by PCR-RFLP analysis of ITS1 region. Fish Sci 74:511-515

Gardner JPA, Thompson RJ (2009) Influence of genotype and geography on shell shape and morphometric trait variation among North Atlantic blue mussel (Mytilus spp.) populations. Biol J Linn Soc 96:875-897

Gaspar MB, Monteiro CC (1998) Reproductive cycles of the razor clam Ensis siliqua and the clam Venus striatula off Vilamoura, southern Portugal. J Mar Biol Assoc UK 78:1247-1258

Gaspar MB, Castro M, Monteiro CC (1999) Effect of tooth spacing and mesh size on the catch of the Portuguese clam and razor clam dredge. ICES J Mar Sci 56:103-110

Goodfriend GA (1986) Variation in land-snail shell form and size and its causes-a review. Syst Zool 35:204-223

Gordillo S, Márquez F, Cárdenas J, Zubimendi MÁ (2011) Shell variability in Tawera gayi (Veneridae) from southern South America: a morphometric approach based on contour analysis. J Mar Biol Assoc UK 91:815-822

Guerra A, Lodeiros C (2008) Navajas y longueirones: biologia, pesquerias y cultivo. Conselleria de Pesca e Asuntos Marítimos, Xunta de Galicia, Santiago de Compostela

Hauton C, Atkinson RJA, Moore PG (2003a) The impact of hydraulic blade dredging on a benthic megafaunal community in the Clyde Sea area, Scotland. J Sea Res 50:45-56

Hauton C, Hall-Spencer JM, Moore PG (2003b) An experimental study of the ecological impacts of hydraulic bivalve dredging on maerl. ICES J Mar Sci 60:381-392

Henderson SM, Richardson CA (1994) A comparison of the age, growth rate and burrowing behaviour of the razor clams, Ensis siliqua and E. ensis. J Mar Biol Assoc UK 74:939-954

Innes DJ, Bates JA (1999) Morphological variation of Mytilus edulis and Mytilus trossulus in eastern Newfoundland. Mar Biol 133:691-699

Jarek S (2009) mvnormtest: normality test for multivariate variables. $\mathrm{R}$ package version 0.1-7

Krapivka S, Toro JE, Alcapán AC, Astorga M, Presa P, Pérez M, Guiñez R (2007) Shell-shape variation along the latitudinal range of the Chilean blue mussel Mytilus chilensis (Hupe 1854). Aquacult Res 38:1770-1777

Lawing AM, Polly PD (2009) Geometric morphometrics: recent applications to the study of evolution and development. J Zool 280:1-7

Madec L, Bellido A, Guiller A (2003) Shell shape of the land snail Cornu aspersum in North Africa: unexpected evidence of a phylogeographical splitting. Heredity 91:224-231
Márquez F, Van der Molen S (2011) Intraspecific shell-shape variation in the razor clam Ensis macha along the Patagonian coast. J Mollus Stud 77:123-128

Márquez F, Amoroso R, Sainz MFG, Van der Molen S (2010a) Shell morphology changes in the scallop Aequipecten tehuelchus during its life span: a geometric morphometric approach. Aquat Biol 11:149-155

Márquez F, Robledo J, Peñaloza GE, Van der Molen S (2010b) Use of different geometric morphometrics tools for the discrimination of phenotypic stocks of the striped clam Ameghinomya antiqua (Veneridae) in north Patagonia, Argentina. Fish Res 101:127131

McClain CR, Johnson NA, Rex MA (2004) Morphological disparity as a biodiversity metric in lower bathyal and abyssal gastropod assemblages. Evolution 58:338-348

McGhee GR Jr (1999) Theoretical morphology. Columbia University Press, New York

Oksanen J, Blanchet FG, Kindt R, Legendre P, O’Hara RB, Simpson GL, Solymos P, Stevens MHH, Wagner H (2010) vegan: community ecology package. $\mathrm{R}$ package version 1.17-4. http://CRAN.R-project.org/package=vegan

Palmer M, Pons GX, Linde M (2004) Discriminating between geographical groups of a Mediterranean commercial clam (Chamelea gallina (L.): Veneridae) by shape analysis. Fish Res 67:93-98

Peliz A, Marchesiello P, Dubert J, Marta-Almeida M, Roy C, Queiroga H (2007) A study of crab larvae dispersal on the Western Iberian Shelf: physical processes. J Mar Syst 68:215236

Raup DM (1966) Geometric analysis of shell coiling: general problems. J Paleontol 40:1178-1190

R Development Core Team (2010) R: a language and environment for statistical computing. R Foundation for Statistical Computing, Vienna, Austria. URL: http://www.R-project.org

Robinson RF, Richardson CA (1998) The direct and indirect effects of suction dredging on a razor clam (Ensis arcuatus) population. ICES J Mar Sci 55:970-977

Rohlf J (2000) TpsReg. Version 1.26. Department of Ecology and Evolution, State University of New York at Stony Brook, New York

Rohlf J (2003a) TpsDig. Version 1.39. Department of Ecology and Evolution, State University of New York at Stony Brook, New York

Rohlf J (2003b) TpsRel. Version 1.29. Department of Ecology and Evolution, State University of New York at Stony Brook, New York

Rohlf FJ, Archie JW (1984) A comparison of Fourier methods for the description of wing shape in mosquitoes (Diptera: Culicidae). Syst Zool 33:302-317

Roopnarine PD, Signorelli J, Laumer C (2008) Systematic, biogeographic and microhabitat -based morphometric variation of the bivalve Anomalocardia squamosa (Bivalvia: Veneridae: Chioninae) in Thailand. Raffles Bull Zool 18:95-102

Roth VL, Mercer JM (2000) Morphometrics in development and evolution. Am Zool 40:801-810

Rufino MM, Gaspar MB, Pereira AM, Vasconcelos P (2007) The use of shape to distinguish Chamelea gallina and Chamelea striatula (Bivalvia: Veneridae): linear and geometric morphometric methods. J Morphol 267:1433-1440

Rufino MM, Gaspar MB, Pereira A, Maynou F, Monteiro CC (2010) Ecology of megabenthic bivalve communities from sandy beaches on the south coast of Portugal. Sci Mar 74:163-178

Samadi S, Roumégoux A, Bargues MD, Mas-Coma S, Yong M, Pointier JP (2000) Morphological studies of lymnaeid snails from the human fascioliasis endemic zone of Bolivia. J Mollus Stud 66:31-34 
Savazzi E (1989) Burrowing mechanisms and sculptures in recent gastropods. Lethaia 22:31-48

Savazzi E (1990) Biological aspects of theoretical shell morphology. Lethaia 23:195-212

Savazzi E, Jefferies RPS, Signor PW (1982) Modification of the paradigm for burrowing ribs in various gastropods, crustaceans and calcichordates. Neues Jahrb Geol Paläont Abh 164:206-217

Serb JM, Alejandrino A, Otárola-Castillo E, Adams DC (2011) Morphological convergence of shell shape in distantly related scallop species (Mollusca: Pectinidae). Zool J Linn Soc 163: $571-584$

Slice DE (1998) Morpheus et al.: software for morphometric research. Department of Ecology and Evolution, State University of New York, Stony Brook, New York

Sousa R, Freire R, Rufino MM, Méndez J, Gaspar MB, Antunes C, Guilhermino L (2007) Genetic and shell morphological variability of the invasive bivalve Corbicula fluminea (Müller, 1774) in two Portuguese estuaries. Estuar Coast Shelf Sci 74:166-174

Stone JR (1996) The evolution of ideas: a phylogeny of shell models. Am Nat 148:904-929

Stone JR (1999) Theoretical morphology-the concept and its applications. Science 284:746
Tebble N (1966) British bivalve seashells: a handbook of identification. British Museum, Edinburgh

Tuck ID, Bailey N, Harding M, Sangster G, Howell T, Graham N, Breen M (2000) The impact of water jet dredging for razor clams, Ensis spp., in a shallow sandy subtidal environment. J Sea Res 43:65-81

Urdy S, Goudemand N, Bucher H, Chirat R (2010a) Allometries and the morphogenesis of the molluscan shell: a quantitative and theoretical model. J Exp Zool B Mol Dev Evol 314:280-302

Urdy S, Goudemand N, Bucher H, Chirat R (2010b) Growthdependent phenotypic variation of molluscan shells: implications for allometric data interpretation. J Exp Zool B Mol Dev Evol 314:303-326

Valladares A, Manríquez G, Suárez-Isla BA (2010) Shell shape variation in populations of Mytilus chilensis (Hupe 1854) from southern Chile: a geometric morphometric approach. Mar Biol 157:2731-2738

Varela MA, González-Tizón A, Francisco-Candeira M, MartínezLage A (2007) Isolation and characterization of polymorphic microsatellite loci in the razor clam Ensis siliqua. Mol Ecol Notes 7:221-222 